Aletria, Belo Horizonte, v. 31, n. 3, p. 231-234, 2021

(c) $\underset{\mathrm{BY}}{(1)}$

\title{
VERUNSCHK, Micheliny. $O$ som do rugido da onça. São Paulo: Companhia das Letras, 2021. 168 p.
}

\author{
Michelle Márcia Cobra Torre \\ Universidade Federal de Minas Gerais (UFMG), Belo Horizonte, Minas Gerais / Brasil \\ michelletorre@yahoo.com.br
}

https://orcid.org/0000-0002-6515-142X

O som do rugido da onça, romance da escritora e historiadora Micheliny Verunschk, é uma narrativa dividida em três partes, formada por uma variedade de vozes, sendo essas dos povos da floresta, da natureza, dos ancestrais. A obra propõe um diálogo entre o passado e o presente, apoiando-se em vasta pesquisa histórica, mesclando ficção e história. No século XIX, duas crianças indígenas são levadas para a Europa pelos naturalistas Spix e Martius, que estiveram no Brasil em uma grande expedição científica. O romance de Verunschk subverte o olhar eurocêntrico dos naturalistas e conta a história da perspectiva da menina indígena, que recupera a sua voz silenciada, roubada.

Micheliny Verunschk, nesse romance, propõe pensar o Brasil a partir de questões fundamentais e latentes, que possuem suas raízes no passado e que repercutem na atualidade. A violência colonial contra os povos nativos, em todas as suas facetas, é tema central do romance, em que o passado colonial reverbera no século XXI, fricciona, esbarra como ondas incessantes, tal como a violência contra o meio ambiente e contra a infância indígena, o genocídio dos povos da floresta. Imagens do passado colonial se mesclam com imagens atuais de indígenas nas cidades, maltrapilhos. A obra literária aproxima o passado dos olhos do leitor contemporâneo, propondo leituras a partir das inquietações do presente.

Tanto a Literatura, quanto a História, podem recuperar personagens históricos que foram marginalizados em dado período, em dada sociedade, propondo novas leituras do passado. Esse movimento possibilita que as vozes silenciadas de grupos vencidos sejam ouvidas. Mas a Literatura alcança onde a História não pode alcançar. Ela mergulha nos sentimentos e nos pensamentos dos personagens, em sua cosmovisão e em seus mundos 
imagináveis e inimagináveis. É possibilitado, ao leitor, ver pelos olhos de um outro, sentir pelo coração de um outro, os seus medos e os seus sonhos. Ela é uma das formas de mergulhar na alteridade.

Alteridade, em $O$ som do rugido da onça, é ver o mundo pelos olhos de Iñe-e, a menina do povo Miranha, levada para Munique com o menino do povo Juri, entre plantas e animais que, na concepção dos estrangeiros, eram seres exóticos. É ouvir a voz do rio Isar. O rio feminino que corre na Bavária, a voz da natureza, que acolhe Iñe-e e penetra em seu coração confortando a menina com notícias de sua família. É também ouvir a voz ancestral do grande felino Tipai uu, sua forma de esturrar, trovejante, que ecoa na floresta.

$\mathrm{Na}$ fria Munique, Iñe-e está longe de sua família e de sua cultura, impedida de realizar os seus ritos. Sente-se sozinha e perdida. O menino Juri, antes seu inimigo ancestral, passa a ser percebido como um irmão, por dividirem o mesmo destino. Iñe-e foi dada de presente a Martius, que firmou acordo com o pai da indígena para a compra de crianças. Uma das questões trazidas pelo romance é histórica e diz respeito a um dos muitos efeitos provocados pelo colonialismo entre os povos nativos, que é a destruição de núcleos parentais. Muitos indígenas passaram a usar parentes como moeda de troca com os europeus. Se em um dado momento eram vendidos adultos e crianças de povos inimigos, os efeitos do colonialismo levam indígenas negociantes a trocarem pessoas de seu próprio povo, ou seja, seus parentes. O pai de Iñe-e, no romance, é João Manoel, personagem histórico, um indígena que vendia pessoas de seu povo aos europeus em troca de machados e facas. João Manoel é denominado como um tuxaua, alguém que almejava ser como o estrangeiro, mas vivia uma meia vida branca. A retirada de Iñe-e de sua família e de sua cultura é o primeiro e mais violento ato contra a menina, tendo início nesse ato a sua morte.

Iñe-e e o menino Juri são expostos à corte dos reis da Baviera. A exposição é extremamente desagradável e a menina sente como se fosse devorada pelos olhos famintos dos convidados do rei. A exibição de seus corpos configura mais um ato de violência cruel cometido contra as crianças indígenas, que, como outros, foram também levados à Europa e serviram aos apetites curiosos, ávidos por novidades. A todo o momento, as lembranças da aldeia invadem o coração da menina, como as lembranças do calor da mãe e de suas palavras. O sentimento de angústia toma conta de Iñe-e. Em Munique, são batizados como Isabella 
e Johann, tendo seus nomes negados em mais um ato de violência contra suas identidades, suas culturas e suas histórias.

Micheliny Verunschk traz várias palavras indígenas para o romance, familiares a Iñe-e, fruto de uma profunda pesquisa. A nostalgia das palavras aprendidas com sua mãe e o medo de se esquecer do tom ou do timbre da voz de algum parente assombravam Iñe-e. A perda da voz, da cultura e de seu mundo são perdas e violências sofridas pelas crianças indígenas em um mundo que não as compreende.

As diferentes temporalidades se esbarram frequentemente nesse romance e o passado provoca ondas que atingem personagens do presente, como Josefa, que, na obra, é como um elo entre as crianças indígenas levadas por Spix e Martius e os ecos do passado colonial em sua vida presente. Em uma exposição de litogravuras em um centro cultural, Josefa impressiona-se com as imagens da menina e do menino indígenas, o que desencadeia nela uma busca por sua ancestralidade, marcada pela história da bisavó, pega a laço, e que sofrera um apagamento na memória da família. A personagem tem dificuldade em lidar com o passado e foge de algo que ainda não compreende, assim, "Josefa é uma mulher que fugiu. Em todo lugar do mundo, em qualquer tempo, há uma mulher fugindo" (VERUNSCHK, 2021, p. 80). Ela vai para terras distantes para se encontrar consigo mesma e lá tem a sua revelação.

Há que se observar também o profundo trabalho de pesquisa de vocábulos, da cultura e da cosmovisão de povos indígenas. Ao final da obra, a autora relata que consultou histórias dos povos Miranha, Juri e Yanomami, assim como de outros. As referências indígenas relativas à fundação do mundo costuram a narrativa do romance e agregam todas as vozes desses povos nativos em uma ciranda, na terceira parte do livro, lançando luz sobre toda a obra. Micheliny Verunschk traz para o romance, com beleza e profundidade, essas vozes, num momento em que precisam, mais do que nunca, serem ouvidas. Saliente-se que Verunschk se aproxima de narradores indígenas e se afasta de autores indigenistas e das representações canônicas da literatura brasileira sobre os povos indígenas, colocando a sua obra em outro patamar, escapando das armadilhas da tradição literária que a antecede.

Um ponto que não pode deixar de ser trazido à discussão é o belo diálogo com o conto "Meu tio Iauaretê", do escritor mineiro Guimarães Rosa. Para além de $O$ som do rugido da onça resgatar diferentes nomes - tanto indígenas quanto sertanejos - dados a esse grande felino, o jaguar, 
a nossa onça, há outro ponto mais íntimo nessa relação entre os dois textos. O narrador do conto roseano, um caçador de onças, diz ter aprendido os movimentos da caça com o grande felino. Ao longo da narrativa, o onceiro se metamorfoseia em onça e está convencido de que ele é um parente desses felinos do sertão, que o farejam e o reconhecem como tal. Tanto em Guimarães Rosa quanto no romance de Micheliny Verunschk, a onça é o animal que dá medo, mas que também é íntima. A família de Iñe-e acredita que a menina fez um pacto com a onça que ronda a aldeia e que, um dia, ela poderia se transformar no grande felino e matar a todos.

"Iñe-e, tu é minha e, por ser minha, é bom que saiba que tu é onça quando quiser de ser. Mãos tuas viram patas macias, orelhas tuas se acendem setas, e aqui te surgem bigodes que te ensinam a ser quem tu é e a andar pelos caminhos que tu deve de andar" (VERUNSCHK, 2021, p.113).

A onça, animal importante na cosmovisão de muitos povos indígenas, é carregada de significados no romance de Verunschk. Significados esses que são trazidos para o presente em uma obra delicada, forte e corajosa, que reivindica uma mirada diferente daqui para frente. Vestir a pele da onça é o que faz a autora nesse belo romance.

Recebido em: 30 de abril de 2021. Aprovado em: 25 de maio de 2021. 
ENTREVISTA

(A) 
